Article

\title{
Phytochemical and Safety Evaluations of Volatile Terpenoids from Zingiber cassumunar Roxb. on Mature Carp Peripheral Blood Mononuclear Cells and Embryonic Zebrafish
}

\author{
Raktham Mektrirat $^{1,2}{ }^{\mathbb{D}}$, Terdsak Yano ${ }^{3}(\mathbb{D})$, Siriporn Okonogi ${ }^{2,4}$, Wasan Katip ${ }^{5}$ and \\ Surachai Pikulkaew 2,3,* \\ 1 Department of Veterinary Biosciences and Public Health, Faculty of Veterinary Medicine, Chiang Mai \\ University, Chiang Mai 50100, Thailand; raktham.m@cmu.ac.th \\ 2 Research Center for Pharmaceutical Nanotechnology, Chiang Mai University, Chiang Mai 50200, Thailand; \\ okng2000@gmail.com \\ 3 Department of Food Animal Clinic, Faculty of Veterinary Medicine, Chiang Mai University, \\ Chiang Mai 50100, Thailand; vetjek@gmail.com \\ 4 Department of Pharmaceutical Sciences, Faculty of Pharmacy, Chiang Mai University, \\ Chiang Mai 50200, Thailand \\ 5 Department of Pharmaceutical Care, Faculty of Pharmacy, Chiang Mai University, \\ Chiang Mai 50200, Thailand; wasankatip@gmail.com \\ * Correspondence: surapikulkaew@gmail.com; Tel.: +66-(53)-948-023; Fax: +66-(53)-274-710
}

Received: 30 December 2019; Accepted: 28 January 2020; Published: 30 January 2020

check for updates

\begin{abstract}
Pharmaceutical products of essential oil from Zingiber cassumunar Roxb. are extensively being developed, while the research on their safety is seldom documented. The aim of the present study was to evaluate the phytochemical profile and the effect of cassumunar ginger oil on cell-based assay and the zebrafish model. The essential oil was isolated from fresh rhizomes of $Z$. cassumunar using simultaneous steam-distillation. Chemical composition was analyzed using gas chromatograph coupled to a mass spectrometer (GC-MS). Effect of cassumunar ginger oil on adult carp fish peripheral blood mononuclear cells (PBMCs) was investigated using MTT assay. The embryotoxic and teratogenic effects of cassumunar ginger oil were studied in zebrafish embryos. GC-MS results showed that the essential oil was composed of sabinene (43.54\%) and terpinen-4-ol (29.52\%) as the major phytoconstituents. No fish PBMC cytotoxic effect was observed with the concentration less than $50 \mu \mathrm{g} / \mathrm{mL}$ of cassumunar ginger oil. Our results showed for the first time the embryotoxic and teratogenic effects of cassumunar ginger oil in zebrafish embryos. The result indicated that the cassumunar ginger oil induced zebrafish embryotoxicity in a concentration-dependent manner. At $500 \mu \mathrm{g} / \mathrm{mL}$ of cassumunar ginger oil demonstrated significantly moderated embryotoxicity within $24 \mathrm{~h}(p<0.05)$. The survival rate of $100 \mu \mathrm{g} / \mathrm{mL}$ of cassumunar ginger group was markedly declined to zero at 96 -h post-fertilization (log-rank test, $p=0.001$ ). However, survival rates of zebrafish embryo in the 1 and $10 \mu \mathrm{g} / \mathrm{mL}$ cassumunar ginger groups were more than $90 \%$ throughout the trial period. Moreover, very low teratogenicity to the zebrafish embryo was also observed in 1 and $10 \mu \mathrm{g} / \mathrm{mL}$ of cassumunar ginger groups. Our findings suggest that there is hardly any cytotoxicity, embryotoxicity and teratogenicity at concentrations less than $10 \mu \mathrm{g} / \mathrm{mL}$ of cassumunar ginger oil. However, the toxicity assessment of its pharmaceutical product should prove for further consumer protection.
\end{abstract}

Keywords: Zingiberaceae; essential oil; terpene; cytotoxicity; embryotoxicity; zebrafish 


\section{Introduction}

The perennial angiosperm plants of family Zingiberaceae is distributed widely the tropical climatic areas including Asia, Africa and America [1]. This plant family is a significant bioresource provided various utilizations including food ingredients and spices, medicinal herbs, aromatherapy agents and textile dyes [2]. In the last decades, the phytotherapies of the plant extracts is worldwide exceeding in both human and veterinary medicines [3]. As a consequence, the rhizome of Zingiberaceous plants are a valuable source of terpenes and terpenoids, which exhibits a broad spectrum of biological effects. Plants of the Zingiber genera particularly represent useful herbal remedies under Zingiberaceous plants including Z. cassumunar Roxb., Z. corallinum Hance., Z. nimmonii Dalzell., Z. officinale Rosc., Z. wrayi C.K. Lim. and Z. zerumbet (L.) Smith. [1]. Increasingly, Z. cassumunar (cassumunar ginger) is commonly used as a traditional medicinal plant with treatment of a variety of illnesses in Thailand and many Asian countries [4]. The essential oils of the cassumunar ginger have previously identified the major terpenic compounds containing sabinene and terpinen-4-ol [5,6]. The modern pharmaceutical products of the functional terpenoids from cassumunar ginger have recently been developed because of its pharmacological properties including anti-inflammatory, antifungal and antibacterial efficacies [1,4,7]. The pharmacological efficacy is hindered by the low hydrophilicity of the terpene derivatives; therefore, some thermodynamically stable dosage forms are prepared for overcoming this problem [6]. Therefore, the toxicity assessments of the cassumunar ginger oils are essential to ensure the safety of phytopharmaceuticals, although the acute and the chronic oral toxicity of Z. cassumunar extracts using Organization of Economic Cooperation and Development (OECD) and World Health Organization (WHO) guidelines has been previously reported [8]. Geographical origin is one of the most important aspects that influence the chemical composition of plants. Unfortunately, a review of the literature revealed that there is no documented in the considering embryotoxic and teratogenic assessments of essential oil from Z. cassumunar from Thailand. Therefore, the present research planned to fill this gap.

In recent year, the zebrafish (Danio rerio) has been widely used as animal model in scientific research areas such as genetic model, cancer research and biology development [9]. The zebrafish embryo is a useful small model for investigating vertebrate development because of its rapid development, high fecundity and easy observation of transparent embryos [10]. Interestingly, the processes of development in zebrafish embryo are similar to embryogenesis of other higher vertebrates, including humans [11]. Moreover, the usage of the zebrafish model unforgettably tapers the toxicity studies using the higher vertebrate models. From these benefits, the zebrafish embryo has been considered as an alternative model for vertebrate model for toxicological assessment $[9,10]$, as well as for new drug discovery of herb [12,13]. Recent studies on embryotoxic and developmental toxicity assessments of Curcuma longa Linn. extract using a zebrafish model are reported. [14]. Thus, the current investigation was used the zebrafish embryo model to assessment the embryotoxicity and teratogenicity of essential oil from Z. cassumunar. However, the cell-based toxicity assay should be performed for prognosticating toxicity prior to study in the whole organisms. The ability of the phytoconstituents in inhibiting the cell viability of peripheral blood mononuclear cells (PBMC) is ascertained as an indication of its systemic toxicity. Consequently, the aim of the present study was to identify chemical composition of the cassumunar ginger oil and evaluate its toxicity on in vitro adult carp PBMCs and in vivo zebrafish embryos.

\section{Results}

\subsection{Chemical Compositions of Essential Oil}

The ginger cassumunar oil appeared as a clear pale yellowish liquid. The phytoconstituents were characterized by GC-MS method with a running time of $50 \mathrm{~min}$. A list of the constituents identified in the ginger cassumunar oil and their percentage composition is shown in Table 1. The composition of essential oil was identified by terpenoids $(87.97 \%)$, which consisted mainly of monocyclic monoterpenoids $(87.47 \%)$ and small amounts of sesquiterpenes $(0.52 \%)$. The monoterpenoids were 
divided into the monoterpene hydrocarbons (58.45\%) and the oxygen-containing compounds (29.25\%). Interestingly, an indolizidine alkaloid was present in little amounts $(11.10 \%)$. The chromatogram demonstrated the presence of predominated identifiable spectra (Figure 1). The most abundant compounds were sabinene, accounting for about $43.54 \%$ of the total peak area, followed by terpinen- 4 -ol (29.52\%), 1,2-dimethyl-6-nitroindolizine (11.10\%), and $\gamma$-Terpinene (7.38\%).

Table 1. Chemical composition of essential oil from Z. cassumunar Roxb. obtained by GC-MS analysis. The cassumunar ginger oil was extracted from the rhizomes of Z. cassumunar by simultaneous steam-distillation and analyzed by GC-MS. RT: Retention time; MW: Molecular weight.

\begin{tabular}{cccccc}
\hline Peak & RT (min) & Component & Formula & MW (g/mol) & Amount (\%) \\
\hline 1 & 5.64 & $\alpha$-Thujene & $\mathrm{C}_{10} \mathrm{H}_{16}$ & 136.23 & 0.60 \\
2 & 5.83 & $\alpha$-Pinene & $\mathrm{C}_{10} \mathrm{H}_{16}$ & 136.23 & 1.58 \\
3 & 7.16 & Sabinene & $\mathrm{C}_{10} \mathrm{H}_{16}$ & 136.23 & 43.54 \\
4 & 7.84 & Myrcene & $\mathrm{C}_{10} \mathrm{H}_{16}$ & 136.23 & 1.17 \\
5 & 8.74 & $\alpha$-Terpinene & $\mathrm{C}_{10} \mathrm{H}_{16}$ & 136.23 & 2.82 \\
6 & 9.09 & Benzene & $\mathrm{C}_{6} \mathrm{H}_{6}$ & 78.11 & 0.94 \\
7 & 10.46 & $\mathrm{C}_{10} \mathrm{H}_{16}$ & 136.23 & 7.38 \\
8 & 11.69 & $\alpha$-Terpinene & $\mathrm{C}_{10} \mathrm{H}_{16}$ & 136.23 & 0.84 \\
9 & 15.68 & Terpinen-4-ol & $\mathrm{C}_{10} \mathrm{H}_{18} \mathrm{O}$ & 154.25 & 29.52 \\
10 & 30.24 & $\beta$-Sesquiphellandrene & $\mathrm{C}_{15} \mathrm{H}_{24}$ & 204.35 & 0.52 \\
11 & 34.63 & 1,2-Dimethyl-6-nitroindolizine & $\mathrm{C}_{10} \mathrm{H}_{10} \mathrm{O}_{2} \mathrm{~N}_{2}$ & 190.20 & 11.10 \\
\hline
\end{tabular}

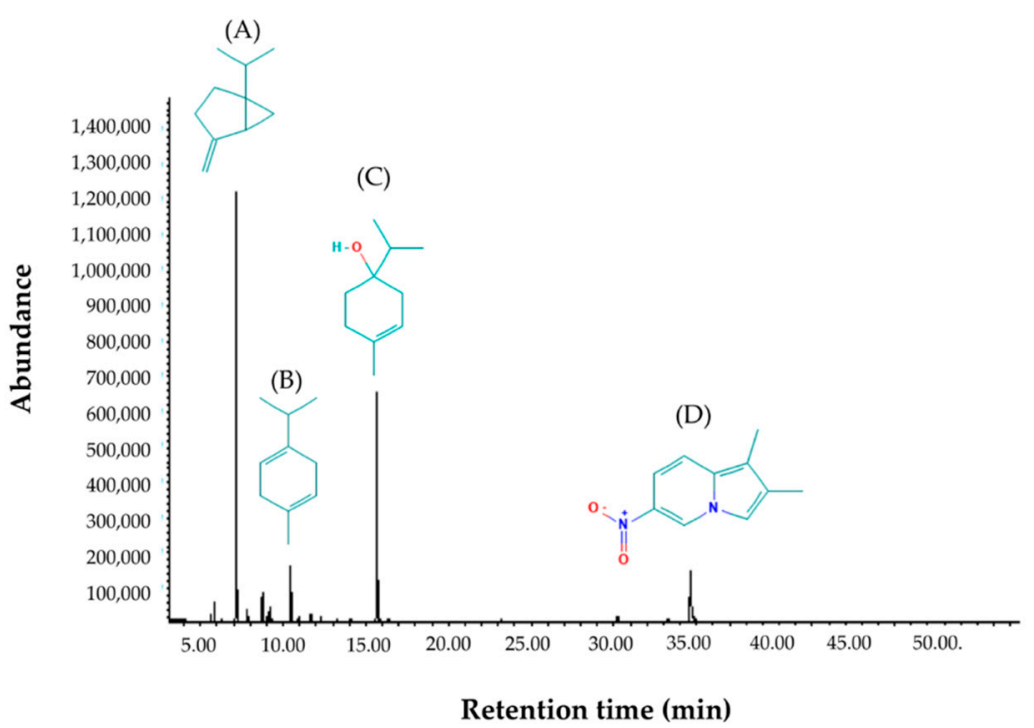

Figure 1. GC-MS chromatograph for essential oil isolated from Zingiber cassumunar Roxb. The phytoconstituents were characterized by a GC-MS method with a running time of $50 \mathrm{~min}$. Chemical structures of the four major constituents identified from the cassumunar ginger oil including

(A) Sabinene, (B) $\gamma$-Terpinene, (C) 4-Terpineol and (D) 1,2-Dimethyl-6-nitroindolizine.

\subsection{Cytotoxicity on Adult Fish PBMCS}

To examine the essential oil from Z. cassumunar induced cytotoxicity, cell viability for PBMCs of adult carp fish was determined using MTT reduction assay. The cell viability was represented by the detection of enzyme mitochondrial dehydrogenase activity. The cytotoxic effect of the cassumunar ginger oil on PBMCs for $24 \mathrm{~h}$ was shown in Figure 2. The results summarized that the cassumunar ginger oil induced PBMCs cytotoxicity in a concentration-dependent manner. The viability rate of the PBMCs from the control group was 100\%, while that of the PBMCs treated with 5, 10, 50, 100 and $500 \mu \mathrm{g} / \mathrm{mL}$ of the cassumunar ginger oils was $89.75 \pm 3.04 \%, 82.32 \pm 6.12 \%, 71.08 \pm 1.92,62.94 \pm 4.73$ and $59.25 \pm 5.73 \%$, respectively. The essential oil concentrations of 100 and $500 \mu \mathrm{g} / \mathrm{mL}$ exhibited significantly higher cytotoxicity than that of the concentration range at 5 and $10 \mu \mathrm{g} / \mathrm{mL}(p<0.05)$. 
On the other hand, the cassumunar ginger oils at the concentration less than $50 \mu \mathrm{g} / \mathrm{mL}$ were not significantly toxic to the PBMCs by this assay.

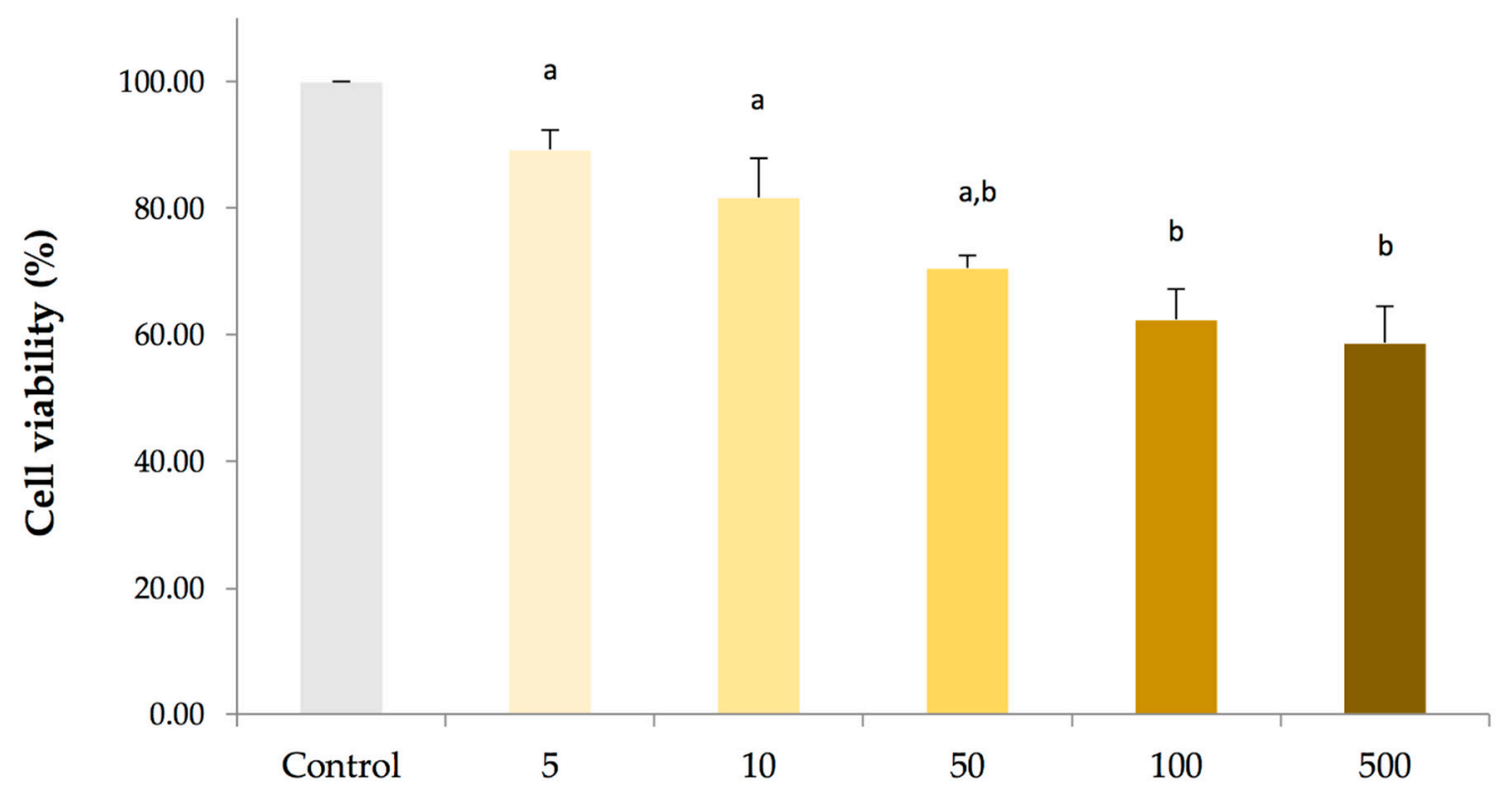

\section{Concentrations $(\mu \mathrm{g} / \mathrm{mL})$}

Figure 2. The cytotoxic effect of essential oil from Zingiber cassumunar Roxb. on adult carp fish PBMCs. The cells were treated with a series of concentrations in the range $5-500 \mu \mathrm{g} / \mathrm{mL}$ for $24 \mathrm{~h}$. Percentages of cell viability were calculated from the PBMCs exposed to $0.1 \%$ DMSO (control), and 5, 10, 50, 100 and $500 \mu \mathrm{g} / \mathrm{mL}$ essential oils. Data represent the mean ( \pm standard deviation, SD) of four independent experiments. Experiments were analyzed using two-way ANOVA and Tukey's multiple comparison test. Bars not sharing a common letter are significantly different $(p<0.05)$.

\subsection{Dose-response Embryotoxicity in Zebrafish}

The embryotoxicity was determined at multiple concentrations of the cassumunar ginger oils (5, 10, 50, 100 and $500 \mu \mathrm{g} / \mathrm{mL}$ ) prior to evaluating its killing-kinetic effect. Absence of larvae heartbeat and coagulation of embryo were used as criteria to differentiate viable from non-viable zebrafish embryo (Figure 5B). Our results revealed that the toxic effect of cassumunar ginger oils were found to be dependent on dose. The mean mortality of zebrafish embryo at $24 \mathrm{~h}$ was obtained as shown in Figure 3 . The results summarized that no mortality was observed in embryos exposed to $0.1 \%$ DMSO (control) and $5 \mu \mathrm{g} / \mathrm{mL}$ of the cassumunar ginger oils. A few mortality rates of embryos exposed treated with $10,50,100 \mu \mathrm{g} / \mathrm{mL}$ of the cassumunar ginger oils was $2.50 \pm 5.00 \%, 2.50 \pm 5.00 \%$, and $15.00 \pm 5.77 \%$, respectively. Significantly increasing mortality rates $(p<0.05)$ were demonstrated in treatment at $500 \mu \mathrm{g} / \mathrm{mL}$ when compared with the low concentration of cassumunar ginger oils ( $\leq 100 \mu \mathrm{g} / \mathrm{mL})$.

\subsection{Time-kill Analysis in Zebrafish Embryos}

The study of dose-response embryotoxicity suggested that a value corresponding to the maximum safety concentration on zebrafish embryos are given at $100 \mu \mathrm{g} / \mathrm{mL}$ of the cassumunar ginger oils. Therefore, the time-kill analysis of three different concentrations of cassumunar ginger oils $(1,10$ and $100 \mu \mathrm{g} / \mathrm{mL}$ ) was performed to evaluate the kinetic killing of zebrafish embryos at 24, 48, 72 and $96 \mathrm{~h}$. The Kaplan-Meier curve is used to demonstrate the survival time from a certain date to time of zebrafish embryo death (Figure 4). The result showed that the killing ability of cassumunar ginger oil was performed in a time dependent manner. However, survival rates of embryo in the control, 1 and 
$10 \mu \mathrm{g} / \mathrm{mL}$ of cassumunar ginger groups were more than $90 \%$ throughout the trial period. Whereas, the survival rate of $100 \mu \mathrm{g} / \mathrm{mL}$ of cassumunar ginger groups was markedly declined to zero at $96 \mathrm{~h}$ post-exposure observation time (log-rank test, $p=0.001)$.

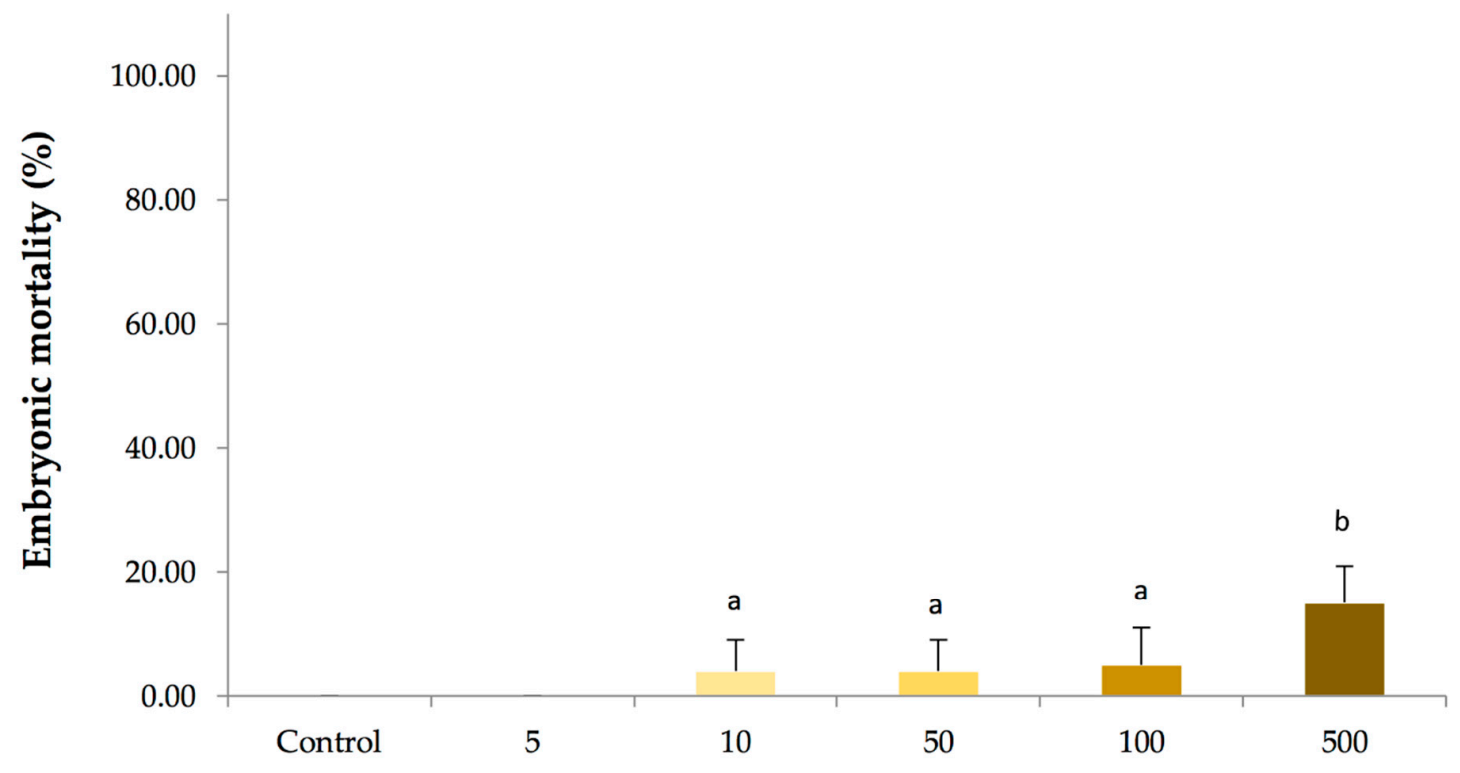

Concentrations $(\mu \mathrm{g} / \mathrm{mL})$

Figure 3. The embryotoxic effect of various concentrations of essential oil from Zingiber cassumunar Roxb. in embryonic zebrafish. The zebrafish embryos were treated with a series of concentrations in the range $5-500 \mu \mathrm{g} / \mathrm{mL}$ Percentages of embryonic mortality were calculated from zebrafish embryos exposed to $0.1 \%$ DMSO (control), and 5, 10, 50, 100 and $500 \mu \mathrm{g} / \mathrm{mL}$ of the cassumunar ginger oils. Data represent the mean $\pm \mathrm{SD}$ of four independent experiments ( $n=40$ per group). Experiments were analyzed using two-way ANOVA and Tukey's multiple comparison test. Bars not sharing a common letter are significantly different $(p<0.05)$.

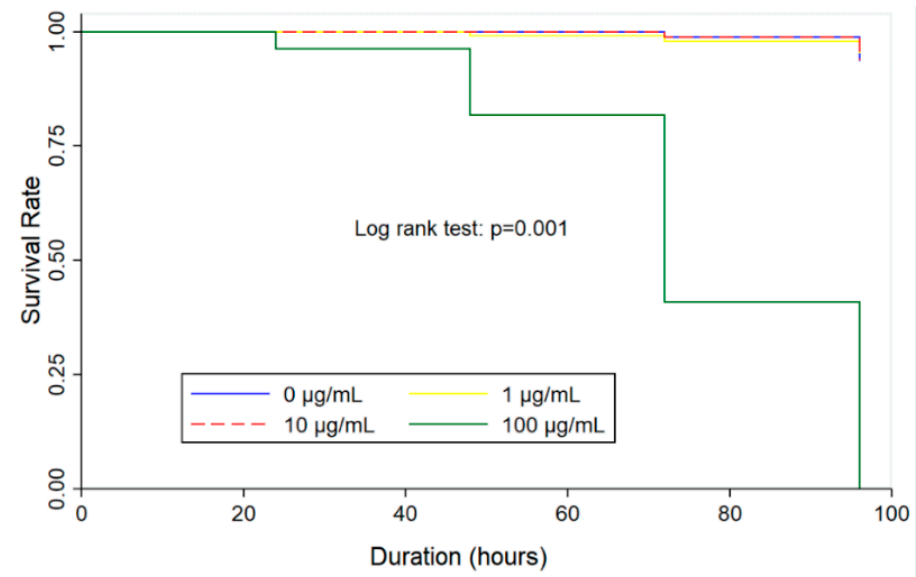

Figure 4. The embryotoxic effect of essential oil from Zingiber cassumunar Roxb. on time-killing in embryonic zebrafish. The zebrafish embryos were exposed to $0.1 \%$ DMSO (control), and 1, 10 and $100 \mu \mathrm{g} / \mathrm{mL}$ of the cassumunar ginger oils. Kaplan-Meier plot represents survival rate in four different groups of four independent experiments ( $n=40$ per group). The Log Rank test was used for statistical analysis $(p<0.01)$. 


\subsection{Teratogenicity in Zebrafish}

To examine the essential oil from $Z$. cassumunar induced teratogenicity, the zebrafish embryos were determined at multiple concentrations of the cassumunar ginger oils $(1,10$ and $100 \mu \mathrm{g} / \mathrm{mL})$ during range of exposure time $24-96 \mathrm{~h}$. The teratogenic effect of the cassumunar ginger oil in zebrafish embryos was shown in Table 2. The result illustrated that the malformation rate of embryonic zebrafish exposed to 10 and $100 \mu \mathrm{g} / \mathrm{mL}$ of cassumunar ginger oils for $24 \mathrm{~h}$ was $1 \pm 0.8 \%$ and $24.5 \pm 6.6 \%$, respectively. The embryonic morphology was observed including the malformation of yolk sac and the malformation of head and tail development (Figure 5D). Surprisingly, accumulative abnormality to the zebrafish embryo was not found in all experiment groups at $48 \mathrm{~h}$. However, some remaining embryos that were exposed to $100 \mu \mathrm{g} / \mathrm{mL}$ showed pericardial sac edema, the abnormality of the spinal column and the poor reabsorption of yolk sac (Figure $5 \mathrm{~F}, \mathrm{H}$ ) with $10.5 \pm 1.9 \%$ at $72 \mathrm{~h}$. Mortality rate of $100 \%$ was observed at $96 \mathrm{~h}$ after exposure to $100 \mu \mathrm{g} / \mathrm{mL}$ of cassumunar ginger oils and all embryos were defined as coagulation of embryo (Figure 5B). Interestingly, no teratogenic abnormality of the zebrafish embryo was found in control and $1 \mu \mathrm{g} / \mathrm{mL}$ groups throughout the trial period. (Figure 5A,E).

Table 2. Teratogenic effects of essential oil from Zingiber cassumunar Roxb. on early development of zebrafish. The zebrafish embryos were treated to $0.1 \%$ DMSO (control), and 1, 10 and $100 \mu \mathrm{g} / \mathrm{mL}$ of the cassumunar ginger oils at different times of exposure (24, 48, 72 and $96 \mathrm{~h})$. Descriptive data represent the mean \pm SD of teratogenic embryo percentage of four independent experiments ( $n=40$ per group). $\mathrm{NE}=$ no surviving embryo.

\begin{tabular}{ccccc}
\hline \multirow{2}{*}{$\begin{array}{c}\text { Concentrations } \\
(\mu \mathrm{g} / \mathrm{mL})\end{array}$} & $\mathbf{4}$ & $\mathbf{4 8}$ & $\mathbf{7 2}$ & $\mathbf{9 6}$ \\
\cline { 2 - 5 } & 0 & 0 & 0 & 0 \\
0 & 0 & 0 & 0 & 0 \\
1 & $1.0 \pm 0.8$ & 0 & 0 & 0 \\
10 & $24.5 \pm 6.6$ & 0 & $10.5 \pm 1.9$ & $\mathrm{NE}$ \\
\hline
\end{tabular}

Control

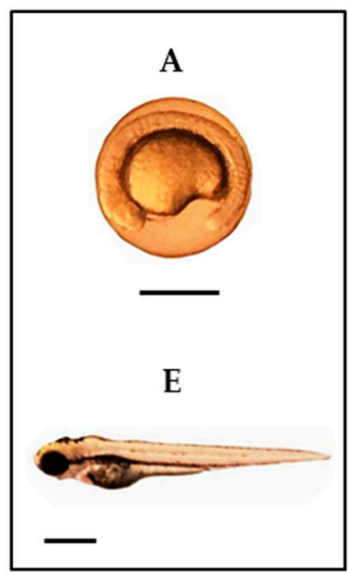

Cassumunar ginger oil exposure

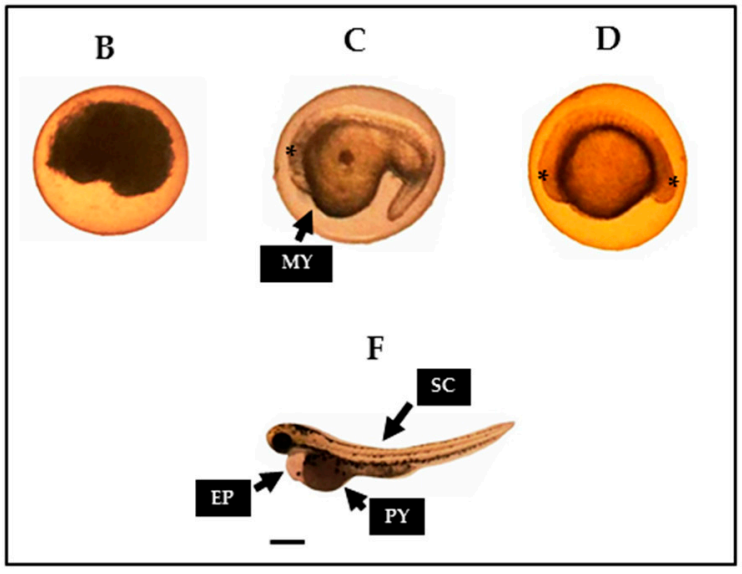

Figure 5. Effect of essential oil from Zingiber cassumunar Roxb. on typical malformations in zebrafish embryos. The zebrafish embryos were exposed to 0.1\% DMSO (control), and 1, 10 and 100 of the cassumunar ginger oils. The normal morphology of zebrafish embryo and larvae exposure to filtered water and to $0.1 \%$ DMSO (control) at $24 \mathrm{~h} \mathrm{(A)} \mathrm{and} 72 \mathrm{~h}$ (E). Typical malformations caused by $100 \mu \mathrm{g} / \mathrm{mL}$ of cassumunar ginger oils on zebrafish embryonic development at $24 \mathrm{~h}(\mathbf{B}, \mathbf{C}, \mathbf{D})$ and $72 \mathrm{~h}(\mathbf{F})$. Description: coagulation (B) and embryo with teratogenic effect $(\mathbf{C}, \mathbf{D}, \mathbf{F})$. Abbreviations: MY, malformation of yolk sac; PY, poor reabsorption of yolk sac; and SC, spinal column curving. (Scale bars $=1 \mu \mathrm{m}$ ). 


\section{Discussion}

Terpenes and their derivatives are worldwide exceeding in both human and veterinary medicine. Fortunately, the essential oil from Z. cassumunar Roxb. was previously characterized as the natural terpenic compounds. The major component including sabinene (53.50\%) and terpinen-4-ol (29.96\%), $\gamma$-Terpinene (7.25\%), and (E)-1-(3,4-dimethoxyphenyl) butadiene (16.16\%) had found in essential oil isolated from a native Thai species of Z. cassumunar [5]. The phytochemical composition of essential oil from Z. montanum Koenig Link ex A. Dietr were also sabinene (56.34\%), terpinen-4-ol $(10.17 \%)$ and $(E)-1-(3,4-d i m e t h o x y p h e n y l)$ butadiene (14.7\%) [15]. These findings are in agreement with our results on cassumunar ginger oil which the major constituents were sabinene (43.54\%), terpinen-4-ol (29.52\%) and $\gamma$-Terpinene (7.38\%), respectively. Our results demonstrated differences in their constituents from an indolizidine alkaloid of 1,2-dimethyl-6-nitroindolizine (11.10\%). On the other hand, the essential oil from Z. cassumunar cultivated in Malaysia showed the distinctive compounds including 6,9,9-tetramethyl-2,6,10-cycloundecatrien-1-one (60.77\%) and $\alpha$-caryophyllene (23.92\%) [16]. The amount and phytochemicals of essential oils are decided by the plant ontogenesis; therefore, the growing season and the harvesting time are the exogenous factors affecting quality and quantity $[15,17]$. The extraction techniques of the distillations and the solvent extractions are also influencing both yield and quality of essential oils [18]. Moreover, the different cultivation areas affecting the phytochemical constituents of Z. montanum have previously been published [15].

The major component of the cassumunar ginger oil consists of monocyclic monoterpenoid with sabinene and terpinen-4-ol were well documented. Moreover, both sabinene and terpinen-4-ol exhibit a broad spectrum of biological effects $[19,20]$. Therefore, many efforts are development of cassumunar ginger oil as a value-added material that is useful as a pharmaceutical excipient for pharmaceutical, cosmetic and food industries [1,21]. In the most interest of the anti-inflammatory activity, attempts have recently been made to derive this cassumunar ginger oil to formulate the tropical preparations for local and systemic administrations. The topical and the transdermal deliveries of cassumunar ginger oil have been successfully developed by microemulsion, gels and patches [6,22-24]. Development of pharmaceutical products from cassumunar ginger oil are extensively growing, while the research on their toxicity is still limited. The acute and chronic oral toxicity of Z. cassumunar extract granules in Sprague-Dawley rats using OECD and WHO guidelines have been previously reported [8]. Their results demonstrated that the animals treated with the granules of Z. cassumunar extract were not showing the clinical signs related to toxicity in both single and chronic administration. Therefore, the oral no-observed-adverse-effect level (NOAEL) in rats was documented at 1,125 mg/kg body weight/day. Unfortunately, there is no documentation considering embryotoxic and teratogenic assessments of essential oil from Z. cassumunar.

The cell-based toxicity assay on adult fish PBMCs was performed for prognosticating toxicity of cassumunar ginger oil prior to study in the whole organism of zebrafish. The cytotoxicity result of the essential oil on adult fish PBMCs was in dose-dependent manner. The concentration at 5, 10 and $50 \mu \mathrm{g} / \mathrm{mL}$ of the essential oils showed low effect to adult fish PBMCs; whereas, the essential oil concentrations of 100 and $500 \mu \mathrm{g} / \mathrm{mL}$ exhibited significantly higher cytotoxicity than that of the low concentration $(\leq 50 \mu \mathrm{g} / \mathrm{mL})$. The mechanisms of cassumunar ginger oil-mediated cell death are difficult to delineate under this methodologic study. In the reaction mixture, MTT is reduced by mitochondrial enzymes of metabolically active cells and the amount of MTT formazan generated is directly proportional to the viable cell number [25]. Therefore, the MTT assay is used for measuring the screening results of cytotoxicity or proliferative effect of the medicinal substances. However, the percentage of cytotoxicity at highest concentration of the essential oils $(500 \mu \mathrm{g} / \mathrm{mL})$ is lower the inhibitory concentration $50 \%\left(\mathrm{IC}_{50}\right)$ in this study. Moreover, a previous study demonstrated that cytotoxicity of purified compounds from crude extract of Z. cassumunar has weak toxic activity with $\mathrm{IC}_{50}$ values of L929 cell line (1263.42 to $\left.2857.83 \mu \mathrm{g} / \mathrm{mL}\right)$ and Vero cell line (1537.83 to $\left.2698.45 \mu \mathrm{g} / \mathrm{mL}\right)$ [26]. These results suggest that cassumunar ginger oil has strong safety on the animal cells exposed directly. 
The effects of cassumunar ginger oil on in vivo embryotoxicity or teratogenicity in zebrafish embryos were investigated. No embryonic mortality or malformation were observed in the low concentration of cassumunar ginger oil $(\leq 10 \mu \mathrm{g} / \mathrm{mL})$. At the concentration of $100 \mathrm{ug} / \mathrm{mL}$, an increase in embryotoxicity by a time-dependent manner was observed. This corresponds to the previous finding on Curcuma longa Linn. extract which exhibited embryotoxicity at high concentrations $(125 \mu \mathrm{g} / \mathrm{mL})$ on developing zebrafish [14]. The zebrafish fed with the essential oil from Pistacia lentiscus Var. chia with high concentrations of 100 and 200 ppm also demonstrated in increased larvae mortality [27]. It is already known from many research reports that both Z. cassumunar and C. longa plants of family Zingiberaceae represent terpenic and phenolic structures. It can readily pass through the cytoplasmic membrane of zebrafish embryos. Effective permeability of terpenic compounds depends on its chemical structure including hydrophobicity, small size, energy of vaporization and degree of unsaturation [28]. Moreover, it is notable that outer membrane enclosing the embryo was uninterruptedly altered with advancing age of embryo development. This alteration of the protective layer has caused in opening and widening of the chorion pore channel; therefore, the increased uptake of external solutes occurred [29].

Current evidence suggests that the essential oil from Z. cassumunar possess certain toxic effects on embryos and development of larvae at high dosage. It should be noted that the toxicity of $Z$. cassumunar are on the basis of their isolated active phytochemical compounds. The pharmaceutical necessities use in pharmaceutical products may also cause toxicity and other disadvantage to the formulation. Therefore, the toxicity assessment of the pharmaceutical product of Z. cassumunar should be studied further. Among the 808 articles of the clinical efficacy and safety on Z. cassumunar previously was identified by a systematic review [30]. Moreover, the pharmacokinetics of the major bioactive components from Z. cassumunar following oral and topical administrations in rats were previously evaluated [31-33]. In drug development, is critical to ensure that the preclinical study properly supports the patient safety and quality of health care. Our results contribute to understanding the developmental toxicity of essential oil which has a predictive value with regard to its safety.

\section{Materials and Methods}

\subsection{Plant Materials}

The fresh rhizomes of cassumunar ginger were purchased from the local market in Chiang Mai, Thailand (Lat $18^{\circ} 47^{\prime} 46.1148^{\prime \prime} \mathrm{N}$ and Long $98^{\circ} 58^{\prime} 45.3468^{\prime \prime} \mathrm{E}$ ). The voucher specimens were deposited at the Herbarium of the Faculty of Pharmacy, Chiang Mai University, Thailand. The rhizomes were cleaned with water and chopped into pieces. The sample was shade dried and powdered using a dry grinder. The powdered material was stored in light-resistant container until used in the extraction studies.

\subsection{Distillation of Essential Oil and Chemical Characterization}

The essential oil was isolated by the simultaneous steam-distillation using a Clevenger apparatus for $3 \mathrm{~h}$. The essential oil obtained was dried and stored in an airtight dark bottle at $-20{ }^{\circ} \mathrm{C}$ until use. Chemical characterizations of the obtained essential oil were analyzed using a gas chromatography-mass spectrometry (GC-MS) method. The GC-MS analysis was performed using a model 6890 gas chromatograph equipped with a 5973 mass-selective detector using HP-5MS column (30 $\mathrm{m} \times 250 \mu \mathrm{m}$ i.d. $\times 0.25 \mu \mathrm{m}$ film thickness). The identification of each compound was based on their retention times relative to those of authentic samples and matching spectral peaks available in Wiley, NIST, and NBS mass spectral libraries. The percentage of each component was calculated based on the total area of all peaks obtained from the oil.

\subsection{Animal and Ethic Statement}

Koi carp (Cyprinus carpio Koi) and Zebrafish (Danio rerio) were obtained from the stock of the Faculty of Veterinary Medicine, Chiang Mai University. Adult fish were kept in the glass tanks using 
filtered tap water ( $\mathrm{pH}$ 7.4-7.6) and held in natural light conditions. Water parameters including temperature and $\mathrm{pH}$ were monitored daily. The fish were fed twice daily with frozen brine shrimp in the morning and with commercial dry feed in the afternoon. Feces were siphoned out of the tanks every day. The experiment was conducted in accordance with the protocols approved by the Animal Ethics Committee, Faculty of Veterinary Medicine, Chiang Mai University (Ethic Permit No. S5/2562).

\subsection{Fish Blood Collection and PBMC Isolation}

The pooled blood samples were collected from twelve anesthetized carp fish. Each of four fish in three independent experiments were recruited into the study. About three $\mathrm{ml}$ of whole blood was collected by caudal venipuncture into a coagulation tubes containing a buffered sodium citrate solution. The PBMCs were isolated by Ficoll gradient centrifugation according to the manufacturer's instructions. Briefly, a stratified sample between $6 \mathrm{~mL}$ of Ficoll-Hypaque and $12 \mathrm{~mL}$ of peripheral blood was prepared and centrifuged at $400 \times g$ for $20 \mathrm{~min}$. the PBMCs were carefully aspirated from the Ficoll-plasma interface and washed three times with sterile phosphate-buffered saline (PBS). The cell viability was assessed by trypan blue exclusion under the light microscope.

\subsection{In Vitro MTT Reduction Assay}

Isolated PBMCs of carp fish were adjusted to $5 \times 10^{5}$ cells $/ \mathrm{mL}$ in RPMI 1640 supplemented with $1 \%$ heat-inactivated fetal bovine serum. The fish PBMCs were treated with various concentration of $0,5,10,50,100$ and $500 \mu \mathrm{g} / \mathrm{mL}$ cassumunar ginger oil and incubated in $5 \% \mathrm{CO}_{2}$ incubator under humidified conditions at $37^{\circ} \mathrm{C}$. Briefly, the solutions were freshly prepared by mixing the appropriate amount of oil and pure solvent DMSO in a sterile tube and subsequently mixing under moderate agitation using a vortex mixer until homogenous. The cytotoxicity was measured by MTT (3-(4,5-dimethylthiazol-2-yl)-2,5-diphenyl tetrazolium bromide) reduction assay at $24 \mathrm{~h}$ after exposure of cassumunar ginger oil. The volume of $10 \mu \mathrm{L}$ of $5 \mathrm{mg} / \mathrm{mL}$ MTT was added into $200 \mu \mathrm{L}$ of cell suspension and incubated for $4 \mathrm{~h}$. The volume of $100 \mu \mathrm{l} 0.1 \mathrm{M} \mathrm{HCl}$ in absolute isopropanol was added after incubation. The colorimetric determination of formazan product was spectrophotometrically measured at $570 \mathrm{~nm}$. Cell viability was expressed as a percentage of the control culture with $0.1 \%$ DMSO.

\subsection{Zebrafish Breeding and Embryo Acquisition}

One male and two female adult zebrafishes were kept during the breeding period. Zebrafish embryos were spawned by natural mating. The fertilized eggs collected and were rinsed with sea salt egg water $(60 \mathrm{mg} / \mathrm{L}$ sea salt and $2 \mathrm{mg} / \mathrm{L}$ methylene blue). Selections of fertilized egg in a stage 3-4 h postfertilization (hpf) were performed under a stereomicroscope (Nikon, Tokyo, Japan). Qualified embryos were maintained at $28.5^{\circ} \mathrm{C}$ in clean petri dishes with previously egg water until analysis.

\subsection{Zebrafish Embryonic Toxicity Test}

\subsubsection{Dose-response Embryotoxicity}

Sample embryotoxicity was determined by means of mortality rate in the zebrafish embryos. Briefly, the zebrafish embryos $(n=10)$ were transferred to individual wells of 24-well plates. The embryos were exposed to various concentrations of essential oil from Z. cassumunar in DMSO $(100 \mathrm{mg} / \mathrm{mL})$ to make $0,5,10,50,100$ and $500 \mu \mathrm{g} / \mathrm{mL}$ of final concentration. The embryos were observed under a stereomicroscope at $24 \mathrm{~h}$ post-fertilization (hpf). The identification of death embryo was defined with coagulation of embryo or no visual heartbeat of larvae. The number of dead embryos were recorded, and the mortality rate was calculated.

\subsubsection{Time-killed Analysis}

The killing kinetic of essential oil from Z. cassumunar was performed to determine the time killing rates of Zebrafish embryos. Briefly, ten fertilized eggs $(n=10)$ for each concentration of treatment 
essential oil from Z. cassumunar were studied. The experiment was performed in four independent replicates in a 24-well plate containing $2 \mathrm{~mL}$ of embryo media with $0.1 \%$ DMSO containing $100 \mu \mathrm{g}$ of essential oil from Z. cassumunar. It was serially diluted via 10 -fold serial dilution to produce 3 different concentrations of essential oil from $Z$. cassumunar. The death embryos were identified under a stereomicroscope and the time-killed analysis was studied at 24, 48, 72 and $96 \mathrm{~h}$. The data was recorded, and the Kaplan-Meier curve was generated.

\subsection{Zebrafish Teratogenicity Test}

Sample teratogenicity was determined by morphological appearance and development of the zebrafish embryos. Briefly, the zebrafish embryos $(n=10)$ were transferred to individual wells of 24-well plates containing the essential oil from Z. cassumunar $(0,5,10,50,100$ and $500 \mu \mathrm{g} / \mathrm{mL}$ of final concentration). After incubation, the morphological defects of the exposed embryos were evaluated every $24 \mathrm{~h}$ under a stereomicroscope. Embryonic morphology was determined according to OECD test guidelines [34] and normal development of embryo was compared with previous described by Kimmel et al. [11]. The teratogenicity was assessed by descriptive determining the percentage of embryos or larvae with abnormality over remaining embryos.

\subsection{Statistical Analysis}

The experiments were done with four independent replications of each treatment and each killing time of study. The PBMC viability and the mortality of zebrafish embryos were compared by means of two-way analysis of variance (ANOVA) and Tukey's multiple comparison test using R analysis program. All data are presented as mean \pm standard deviation of the mean (SD), and the probabilities less than 0.05 were considered significant. Statistical analysis of killing time was performed using Stata software, version 14 (Stata-Corp, College Station, TX). Differences between the four groups in rates of time to outcome, was compared using the Kaplan-Meier curve and the log-rank test for significance.

\section{Conclusions}

This present research has indicated that the phytochemical characterization of cassumunar ginger oil has demonstrated sabinene and 4-terpineol as the major composition, along with other volatile compounds to sum a total of 11 identified phytoconstituents. Our results highlighted for the first study of embryotoxicity and teratogenicity of essential oil isolated from Z. cassumunar Roxb. This study provides safety information of cassumunar ginger oil in the cell-based toxicity assay and the zebrafish model. The cassumunar ginger oil at the concentration less than $50 \mu \mathrm{g} / \mathrm{mL}$ was not toxic to the adult fish PMMCs by MTT reduction test, whereas, no embryotoxicity and teratogenicity since $10.8 \%$ teratogenic effect is not significant. However, the toxicity assessment of its pharmaceutical product should prove for further consumer protection.

Author Contributions: Project administration and conceptualization, R.M., S.P. and S.O.; methodology, investigation and validation, R.M. and S.P.; data curation, formal analysis and visualization, R.M., S.P., T.Y., and W.K.; original draft preparation, R.M. and S.P.; review, editing and approval of final draft, R.M. and S.P. All authors have read and agreed to the published version of the manuscript.

Funding: The authors are grateful for the financial support received from the National Research Council of Thailand (NRCT).

Acknowledgments: This research work was partially supported by Chiang Mai University. The authors are thankful for the Research Center of Pharmaceutical Nanotechnology and the Research Center of Producing and Development of Products and Innovations for Animal Health and Production, Chiang Mai University for the facility and instrument support.

Conflicts of Interest: The authors declare no conflict of interest. 


\section{References}

1. Sharifi-Rad, M.; Varoni, E.M.; Salehi, B.; Sharifi-Rad, J.; Matthews, K.R.; Ayatollahi, S.A.; Kobarfard, F.; Ibrahim, S.A.; Mnayer, D.; Zakaria, Z.A.; et al. Plants of the Genus Zingiber as a Source of Bioactive Phytochemicals: From Tradition to Pharmacy. Molecules 2017, 22, 2145. [CrossRef] [PubMed]

2. Sharifi-Rad, J.; Sureda, A.; Tenore, G.C.; Daglia, M.; Sharifi-Rad, M.; Valussi, M.; Tundis, R.; Sharifi-Rad, M.; Loizzo, M.R.; Ademiluyi, A.O.; et al. Biological Activities of Essential Oils: From Plant Chemoecology to Traditional Healing Systems. Molecules 2017, 22, 70. [CrossRef] [PubMed]

3. Ghosh, S.; Majumder, P.B.; Mandi, S.S. Species-specific AFLP markers for identification of Zingiber officinale, Z. montanumand, Z. zerumbet (Zingiberaceae). Genet. Mol. Res. 2011, 10, 218-229. [CrossRef] [PubMed]

4. Singh, C.B.; Manglembi, N.; Swapana, N.; Chanu, S.B. Ethnobotany, Phytochemistry and Pharmacology of Zingiber cassumunar Roxb. (Zingiberaceae). J Pharmacogn. Phytochem. 2015, 4, 1-6.

5. Sukatta, U.; Rugthaworn, P.; Punjee, P.; Chidchenchey, S.; Keeratinijakal, V. Chemical composition and physical properties of oil from Plai (Zingiber cassumunar Roxb.) obtained by hydrodistillation and hexane extraction. Kasetsart J. (Nat. Sci.) 2009, 43, 212-217.

6. Chaiyana, W.; Anuchapreeda, S.; Leelapornpisid, P.; Phongpradist, R.; Viernstein, H.; Mueller, M. Development of microemulsion delivery system of essential oil from Zingiber cassumunar Roxb. rhizome for improvement of stability and anti-inflammatory activity. AAPS PharmSciTech 2017, 18, 1332-1342. [CrossRef]

7. Boonyanugomol, W.; Kraisriwattana, K.; Rukseree, K.; Boonsam, K.; Narachai, P. In vitro synergistic antibacterial activity of the essential oil from Zingiber cassumunar Roxb against extensively drug-resistant Acinetobacter baumannii strains. J. Infect. Public Health 2017, 10, 586-592. [CrossRef]

8. Koontongkaew, S.; Poachanukoon, O.; Sireeratawong, S.; Decatiwongse Na Ayudhya, T.; Khonsung, P.; Jaijoy, K.; Soawakontha, R.; Chanchai, M. Safety evaluation of Zingiber cassumunar roxb rhizome extract: Acute and chronic toxicity studies in rats. Int. Sch. Res. Not. 2014, 16, 1-14.

9. Nishima, Y.; Inoue, A.; Sasagawa, S.; Koiwa, J.; Kawaguchi, K.; Kawase, R.; Maruyama, T.; Kim, S.; Tanaka, T. Using zebrafish in systems toxicology for developmental toxicity testing. Congenit. Anom. (Kyoto) 2016, 56, 18-27. [CrossRef]

10. Tran, S.; Facciol, A.; Gerlai, R. The Zebrafish, a Novel Model Organism for Screening Compounds Affecting Acute and Chronic Ethanol-Induced Effects. Int. Rev. Neurobiol. 2016, 126, 467-484.

11. Kimmel, C.B.; Ballard, W.W.; Kimmell, S.R.; Ullmann, B.; Schilling, T.F. Stages of embryonic development of the zebrafish. Dev. Dyn. 1995, 203, 253-310. [CrossRef] [PubMed]

12. Falcão, M.A.P.; de Souza, L.S.; Dolabella, S.S.; Guimarães, A.G.; Walker, C.I.B. Zebrafish as an alternative method for determining the embryo toxicity of plant products: a systematic review. Environ. Sci. Pollut. Res. Int. 2018, 25, 35015-35026. [CrossRef] [PubMed]

13. Yang, J.B.; Li, W.F.; Liu, Y.; Wang, Q.; Chen, X.L.; Wang, A.G.; Jin, H.T.; Ma, S.C. Acute toxicity screening of different extractions, components and constituents of Polygonum multiflorum Thunb. on zebrafish (Danio rerio) embryos in vivo. Biomed. Pharmacother. 2018, 99, 205-213. [CrossRef] [PubMed]

14. Alafiatayo, A.A.; Lai, K.S.; Syahida, A.; Mahmood, M.; Shaharuddin, N.A. Phytochemical evaluation, embryotoxicity, and teratogenic effects of Curcuma longa extract on zebrafish (Danio rerio). Evid. Based Complement Alternat. Med. 2019, 10, 3807207. [CrossRef] [PubMed]

15. Manochai, B.; Paisooksantivatana, Y.; Choi, H.; Hong, J.H. Variation in DPPH scavenging activity and major volatile oil components of cassumunar ginger, Zingiber montanum (Koenig), in response to water deficit and light intensity. Sci. Hortic. 2010, 126, 462-466. [CrossRef]

16. Kamazeri, T.S.A.T.; Samah, O.A.; Taher, M.; Susanti, D.; Qaralleh, H. Antimicrobial activity and essential oils of Curcuma aeruginosa, Curcuma mangga, and Zingiber cassumunar from Malaysia. Asian Pac. J. Trop. Med. 2012, 5, 202-209. [CrossRef]

17. Younis, A.; Riaz, A.; Khan, M.A.; Khan, A.A. Effect of Time of Growing Season and Time of Day for Flower Harvest on Flower Yield and Essential Oil Quality and Quantity of Four Rosa Cultivars. Floric. Ornam. Biotech. 2009, 3, 98-103.

18. Akram, A.; Younis, A.; Akhtar, G.; Ameer, K.; Farooq, A.; Hanif, M.A.; Saeed, M.; Lim, K. Comparative Efficacy of Various Essential Oil Extraction Techniques on Oil Yield and Quality of Jasminum sambac L. Sci. Int. 2017, 5, 84-95. [CrossRef] 
19. Sharma, S.; Gupta, J.; Prabhakar, P.K.; Gupta, P.; Solanki, P.; Rajput, A. Phytochemical Repurposing of Natural Molecule: Sabinene for Identification of Novel Therapeutic Benefits Using In Silico and In Vitro Approaches. Assay Drug Dev. Technol. 2019, 17, 339-351. [CrossRef]

20. Pazyar, N.; Yaghoobi, R.; Bagherani, N.; Kazerouni, A. A review of applications of tea tree oil in dermatology. Int. J. Dermatol. 2013, 52, 784-790. [CrossRef]

21. Li, M.X.; Bai, X.; Ma, Y.P.; Zhang, H.X.; Nama, N.; Pei, S.J.; Du, Z.Z. Cosmetic potentials of extracts and compounds from Zingiber cassumunar Roxb. rhizome. Ind. Crop Prod. 2019, 141, 111764. [CrossRef]

22. Suksaeree, J.; Charoenchai, L.; Madaka, F. Zingiber cassumunar blended patches for skin application: formulation, physicochemical properties, and in vitro studies. Asian J. Pharm. Sci. 2015, 10, 341-349. [CrossRef]

23. Priprem, A.; Janpim, K.; Nualkaew, S.; Mhakunakorn, P. Topical niosome gel of Zingiber cassumunar Roxb. extract for anti-inflammatory activity enhanced skin permeation and stability of compound D. AAPS Pharm. Sci. Tech. 2016, 173, 631-639. [CrossRef] [PubMed]

24. Thaweboon, S.; Thaweboon, B.; Kaypetch, R. Antifungal, Anti-Inflammatory and Cytotoxic Effects of Zingiber cassumunar Gel. Key Eng. Mater. 2018, 773, 360-364. [CrossRef]

25. Van Meerloo, J.; Kaspers, G.J.; Cloos, J. Cell sensitivity assays: the MTT assay. Methods Mol. Biol. 2011, 731, 237-245.

26. Taechowisan, T.; Suttichokthanakorn, S.; Phutdhawong, W.S. Antibacterial and cytotoxicity activities of phenylbutanoids from Zingiber cassumunar Roxb. J. App. Pharm. Sci. 2018, 8, 122-128.

27. Serifi, I.; Tzima, E.; Bardouki, H.; Lampri, E.; Papamarcaki, T. Effects of the Essential Oil from Pistacia lentiscus Var. chia on the Lateral Line System and the Gene Expression Profile of Zebrafish (Danio rerio). Molecules 2019, 24, 3919. [CrossRef]

28. Aqil, M.; Ahad, A.; Sultana, Y.; Ali, A. Status of terpenes as skin penetration enhancers. Drug Discov. Today 2007, 12, 1061-1067. [CrossRef]

29. Ali, M.K.; Saber, S.P.; Taite, D.R.; Emadi, S.; Irving, R. The protective layer of zebrafish embryo changes continuously with advancing age of embryo development (AGED). J. Toxicol. Pharmacol. 2017, 1, 9.

30. Chongmelaxme, B.; Sruamsiri, R.; Dilokthornsakul, P.; Dhippayam, T.; Kongkaew, C.; Saokaew, S.; Chuthapultti, A.; Chaiyakunapruk, N. Clinical effects of Zingiber cassumunar (Plai): A systematic review. Complement. Ther. Med. 2017, 35, 70-77. [CrossRef]

31. Chooluck, K.; Singh, R.P.; Sathirakul, K.; Derendorf, H. Dermal Pharmacokinetics of Terpinen-4-ol Following Topical Administration of Zingiber cassumunar (plai) Oil. Planta Med. 2012, 78, 1761-1766. [CrossRef] [PubMed]

32. Chooluck, K.; Singh, R.P.; Sathirakul, K.; Derendorf, H. Plasma and dermal pharmacokinetics of terpinen-4-ol in rats following intravenous administration. Die Pharmazie 2013, 68, 135-140. [PubMed]

33. Khemawoot, P.; Hunsakunachai, N.; Anukunwithaya, T.; Bangphumi, K.; Ongpipattanakul, B.; Jiratchariyakul, W. Pharmacokinetics of compound D, the major bioactive component of Zingiber cassumunar, in rats. Planta Med. 2016, 82, 1186-1191. [CrossRef] [PubMed]

34. OECD. Guidelines for the Testing of Chemicals. Section 2-Effects on Biotic Systems Test (No 236 Fish Embryo Acute Toxicity (FET) Test); Organization for Economic Cooperation and Development: Paris, France, 2013.

Sample Availability: Samples of the compounds are not available from the authors. 